\title{
Pseudogymnoascus destructans: Causative Agent of White-Nose Syndrome in Bats Is Inhibited by Safe Volatile Organic Compounds
}

\author{
Sally Padhi *, Itamar Dias ${ }^{(\mathbb{D},}$, Victoria L. Korn ${ }^{(\mathbb{D})}$ and Joan W. Bennett \\ Department of Plant Biology, Rutgers University, 59 Dudley Road, New Brunswick, NJ 08901, USA; \\ itamarbraga@gmail.com (I.D.); victoria.korn@rutgers.edu (V.L.K.); profmycogirl@yahoo.com (J.W.B.) \\ * Correspondence: sally.padhi@rutgers.edu; Tel.: +1-848-932-6233
}

Received: 24 February 2018; Accepted: 3 April 2018; Published: 10 April 2018

\begin{abstract}
White-nose syndrome (WNS) is caused by Pseudogymnoascus destructans, a psychrophilic fungus that infects hibernating bats and has caused a serious decline in some species. Natural aroma compounds have been used to control growth of fungal food storage pathogens, so we hypothesized that a similar strategy could work for control of $P$. destructans. The effectiveness of exposure to low concentrations of the vapor phase of four of these compounds was tested on mycelial plugs and conidiospores at temperatures of 5,10 and $15^{\circ} \mathrm{C}$. Here we report the efficacy of vapor phase mushroom alcohol (1-octen-3-ol) for inhibiting mycelial and conidiospore growth of $P$. destructans at 0.4 and $0.8 \mu \mathrm{mol} / \mathrm{mL}$ and demonstrate that the $\mathrm{R}$ enantiomer of this compound is more effective than the $S$ enantiomer, supporting the finding that biological systems can be sensitive to stereochemistry. Further, we report that vapor phase leaf aldehyde (trans-2-hexenal), a common aroma compound associated with cut grass odors and also the major volatile compound in extra virgin olive oil, is more effective than mushroom alcohol. At $0.05 \mu \mathrm{mol} / \mathrm{mL}$, trans-2-hexenal is fungicidal to both conidiospores and mycelia of $P$. destructans.
\end{abstract}

Keywords: bats; white-nose syndrome (WNS); Pseudogymnoascus destructans; volatile organic compounds (VOCs); 1-octen-3-ol (mushroom alcohol); $(R)-(-)-1$-octen-3-ol ( $R$ form); (S)-(+)-1-octen-3-ol (S form); trans-2-hexenal (leaf aldehyde)

\section{Introduction}

White-nose syndrome (WNS), a fungal disease of hibernating bats, has decimated bat populations in North America [1,2] and threatens the extinction of several bat species [3]. WNS probably was introduced to North America from Europe where the disease is endemic but where bats appear to be resistant [4]. The steep declines in North American bat populations make WNS perhaps the most devastating mammalian wildlife disease in recent history [5]. For some bat species, population sizes have declined $99 \%$ in WNS-infected hibernacula $[3,6,7]$.

WNS is caused by Pseudogymnoascus destructans (formerly known as Geomyces destructans), a cold-loving fungus with growth restricted to temperatures of approximately $3-15{ }^{\circ} \mathrm{C}$ and $>90 \%$ relative humidity [8,9]. During hibernation, the body temperature of bats ranges from $2-15{ }^{\circ} \mathrm{C}$ which is similar to the optimum growth temperature for the fungus [10]. The disease infects the cutaneous tissues of bats, producing a white-colored fungal growth on the muzzle and wings [11]. Hibernating bats arouse more frequently from torpor [12-14] resulting in depletion of fat reserves, emaciation and death [15]. WNS pathology also includes changes in electrolyte balance and hydration $[11,16]$, chronic respiratory acidosis [17], immune response [18] and oxidative stress [19]. 
There is a strong need to discover control measures to control $P$. destructans and several studies have shown promise. For example, in in vitro research, the growth of $P$. destructans was inhibited by volatile compounds made by the bacterium Rhodococcus rhodochrous [20,21] and trans, trans-farnesol, a sesquiterpene made by the yeast Candida [22]. Moreover, some preliminary data from our laboratory showed that volatile phase racemic 1-octen-3-ol (mushroom alcohol) could retard the mycelial growth of $P$. destructans, with exposure to $0.8 \mu \mathrm{mol} / \mathrm{mL}$ being fungicidal and exposure to $0.08 \mu \mathrm{mol} / \mathrm{mL}$ being fungistatic [23]. This common fungal volatile exists as two optical isomers or enantiomers: $(R)-(-)-1$-octen-3-ol and $(S)-(+)-1$-octen-3-ol. Chiral discrimination is important in the activity of many biosystems [24], so we have tested the effect of volatilized R- and S- enantiomers of 1-octen-3-ol on the growth of $P$. destructans mycelial plugs and conidiospores.

Plant pathologists have studied a number of generally recognized as safe (GRAS) volatile compounds for use as postharvest fumigants to control mold pathogens in stored fruits and vegetables [25-27]. There are many physiological similarities between plant and animal pathogenic fungi $[28,29]$ so we hypothesized that compounds that worked against common plant pathogenic fungi might also be effective against $P$. destructans. We focused on trans-2-hexenal, an important aroma compound of green plants also known as leaf aldehyde, which is known to have pronounced antimicrobial effects [30-33].

Our fumigation study has been conducted on both mycelia and conidiospores of $P$. destructans. Our long-term aim is to find an antifungal fumigant that will prevent or retard the growth of propagules of this serious bat pathogen but not harm either the hibernating bat or the cave ecosystem. Our immediate goals are as follows: (1) to compare the effects of four concentrations of trans-2-hexenal with the R, S and racemic forms of 1-octen-3-ol on the growth of $P$. destructans at 5,10 and $15^{\circ} \mathrm{C}$; (2) to determine if the growth-inhibiting properties of the four volatilized substances would continue after the fungus is removed from the presence of the VOCs; and (3) having shown that trans-2-hexenal is far more effective than 1-octen-3-ol in inhibiting growth of both mycelia and conidiospores of P. destructans, to test the response of $P$. destructans to extremely low concentrations $(0.01,0.02$ and $0.05 \mu \mathrm{mol} / \mathrm{mL})$ of this six carbon aldehyde for use in implementation of a possible fumigation strategy in bat hibernacula.

\section{Materials and Methods}

\subsection{Chemicals}

Chemical standards of liquid phase racemic 1-octen 3-ol (synonym mushroom alcohol) and trans-2-hexenal (synonyms include trans-2-hexen-1-al, (E)-2-Hexenal, (E)-Hex-2-enal and leaf aldehyde) were purchased from Sigma-Aldrich (St. Louis, MO, USA). The enantiomers (R)-(-)-1-octen-3-ol $(R$ form) and $(S)-(+)-1-o c t e n-3-o l$ ( $S$ form) were gifts from Bedoukian Research, Danbury, CT, USA. The chemical structures of leaf aldehyde and the $R$ - and $S$ - forms of mushroom alcohol are illustrated in Figure 1.

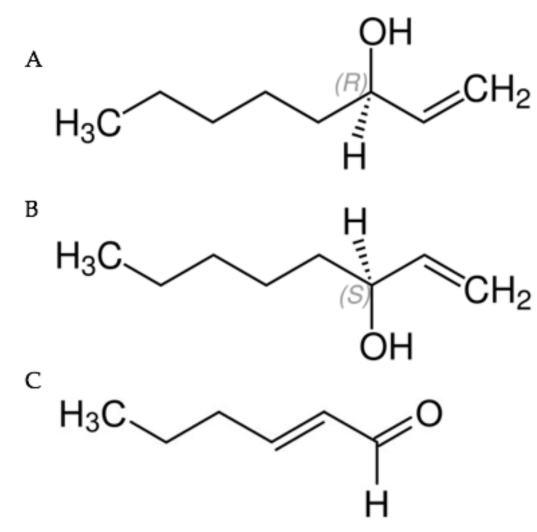

Figure 1. (A) (R)-(-)-1-octen-3-ol ( $R$ form); (B) (S)-(+)-1-octen-3-ol ( $S$ form); (C) trans-2-hexenal. 


\subsection{Fungal Strains and Media}

Pseudogymnoascus destructans, (MYA-4855TM) was obtained from the American Type Culture Collection, Manassas, VA, USA. Throughout our work, P. destructans was handled according to all procedures required for Level 2 classification pathogens. All exposure experiments were conducted with P. destructans grown on Potato Dextrose Agar (PDA) (Difco, Becton, Dickinson \& Company, Sparks, $\mathrm{MD}, \mathrm{USA})$. For the preparation of conidiospores and viable counts of conidiospore concentrations, Sabouraud Dextrose Agar (SDA) (Difco), supplemented with $200 \mathrm{mg} / \mathrm{L} \mathrm{MnSO}_{4}$, was used.

\subsection{Preparation of Fungal Inocula}

To obtain mycelial plugs, fungi were cultured at $15{ }^{\circ} \mathrm{C}$ on PDA for three weeks. Using a \#3 cork borer, mycelial plugs were taken from the actively growing outer edge of 21 day old colonies. To obtain conidiospores of P. destructans, cultures were incubated at $15{ }^{\circ} \mathrm{C}$ for 21 days on SDA. The conidiospores were harvested by adding $10 \mathrm{~mL}$ of CHS (Conidia Harvesting Solution) to each plate and gently scraping the fungal growth with an inoculation loop to help release the spores. CHS was composed of $0.05 \%$ Tween $80 \%$ and $0.9 \% \mathrm{NaCl}$. The suspension was then filtered through glass wool and the flow through was centrifuged at $5000 \mathrm{rpm}$ for $15 \mathrm{~min}$. The supernatant was removed and the conidiospore pellet was re-suspended in $10 \mathrm{~mL}$ of PBS (phosphate-buffered saline) solution at $\mathrm{pH} 7.0[20,21]$.

\subsection{Volatile Exposures}

Plastic split Petri plates $(100 \times 15 \mathrm{~mm})$, also known as I-plates, were used. One half of the plate contained $10 \mathrm{~mL}$ of PDA and the other half contained a sterile glass cover slip $(22 \times 22 \mathrm{~mm})$ for the placement of liquid aliquots of the VOC being tested. The amounts of liquid VOC needed were calculated according to the molarity of the VOC and the volume of the Petri plate. For example, in the highest concentration of trans-2-hexenal tested $(1.0 \mu \mathrm{mol} / \mathrm{mL}), 0.0071 \mathrm{~mL}$ of the liquid standard was placed on a cover slip and allowed to volatilize in the $60 \mathrm{~mL}$ of air space available in the Petri dish.

Mycelial plugs of 21 day cultures were subcultured onto fresh PDA plates and exposed to vapors of $0.05,0.1,0.5$ or $1.0 \mu \mathrm{mol} / \mathrm{mL}$ of trans-2-hexenal, or $0.04,0.08,0.4$ or $0.8 \mu \mathrm{mol} / \mathrm{mL}$ of racemic 1-octen-3-ol, $R$-1-octen 3-ol or S-1-octen 3-ol. Inoculated plates were sealed with two layers of Parafilm. Both 1-octen-3-ol and trans-2-hexenal have a distinctive odor so in order to determine if there was a loss of VOCs from the Petri plates, each VOC treatment was placed in two-liter glass containers with tightly fitting propylene lids. The sealed plates were removed weekly from the two-liter glass containers in order to record growth measurements. The lack of odor indicated a minimal loss of VOCs from the sealed Petri plates. The sealed plates were not opened when the measurements were made so as not to compromise the headspace within the Petri plates.

Plates were incubated at 5,10 or $15^{\circ} \mathrm{C}$ for three weeks and growth measurements were made weekly. The amount of mycelial growth was recorded by averaging two diameter measurements taken on each colony at right angles of each mycelial plug. In a set of parallel VOC exposure experiments conducted at $10{ }^{\circ} \mathrm{C}$, suspensions of conidiospores were spread on I-plates and grown in a shared atmosphere with the four different VOCs using the same parameters as with mycelial plugs.

A second exposure system was designed which would allow the testing of trans-2-hexenal on spore growth in concentrations smaller than $0.05 \mu \mathrm{mol} / \mathrm{mL}$ by increasing the volume of the exposure system. Three $60 \mathrm{~mm}$ Petri plates per treatment were inoculated with conidiospores, the covers removed and the plates placed in two-liter glass containers with tightly fitting propylene lids. trans-2-hexenal was added to the glass containers so that when vaporized the conidiospores would be exposed to 0.005 , $0.01,0.02$ or $0.05 \mu \mathrm{mol} / \mathrm{mL}$ of trans-2-hexenal. The plates were incubated for 3 weeks at $10{ }^{\circ} \mathrm{C}$.

\subsection{Subculture of VOC Treated P. destructans}

After three weeks, in order to determine whether the action of inhibitory VOCs was fungicidal or fungistatic, the mycelial plugs or media containing conidiospore suspensions were removed from the 
presence of volatilized test compounds, transferred to fresh PDA media, sealed with a double layer of Parafilm and placed inside clean, VOC-absent glass containers. The transferred mycelial plugs were incubated for three additional weeks at 5,10 or $15^{\circ} \mathrm{C}$. Three replicates were used per treatment and the experiments were repeated twice. At the end of the three-week period, plates containing mycelial plugs were photographed using a Sony DSC-H9 81 mega pixel camera (Sony Corporation, New York, NY, USA) and a Bio-Rad Universal Hood II with a CCD (couple-charged device) camera using Chemi Doc XRS software (Bio-Rad Laboratory Inc., Hercules, CA, USA). Quantitative data were analyzed using Excel software (Microsoft, Redmond, WA, USA) and Sigma Plot (SPSS Science Inc., Chicago, IL, USA). Error bars indicate standard error (SE) of the mean.

In the second exposure system designed to test trans-2-hexenal in amounts less than $0.05 \mu \mathrm{mol} / \mathrm{mL}$, plates containing VOC treated spores were removed from VOC exposure and covered with sterile fresh covers. The plates were incubated for three more weeks at $10^{\circ} \mathrm{C}$. Three replicates were used per treatment and the experiments were repeated twice. When no growth was observed after three weeks, plates were incubated for another 12 weeks in the absence of VOCs in order to verify that the fungus was no longer viable (i.e., that the VOC exposure was fungicidal).

\section{Results}

\subsection{Growth of VOC Treated Mycelial Plugs}

The effect on the growth of mycelial plugs of P. destructans at 5,10 or $15^{\circ} \mathrm{C}$ from exposure to four concentrations of volatile phase trans-2-hexenal or the three forms of 1-octen-3-ol is shown in graphed form in Figure 2. Controls grew best at $10^{\circ} \mathrm{C}$ with an average increase in mycelial diameter of $200 \mathrm{~mm}$ after three weeks. At $15^{\circ} \mathrm{C}$, controls increased about $130 \mathrm{~mm}$, while at $5^{\circ} \mathrm{C}$ they increased in diameter about $50 \mathrm{~mm}$ during the three-week period. At all three temperature regimes, exposure to the higher concentrations of the four VOCs inhibited growth. The $S$ form of 1-octen-3-ol caused very little growth inhibition at 0.04 and $0.08 \mu \mathrm{mol} / \mathrm{mL}$. At 10 and $15^{\circ} \mathrm{C}, 0.05$ and $0.1 \mu \mathrm{mol} / \mathrm{mL}$ trans-2-hexenal were more effective than 1-octen-3-ol in inhibiting mycelial growth of P. destructans (Figure 2). For all treatments, incubation of the fungus at $5{ }^{\circ} \mathrm{C}$ reduced mycelial growth and also reduced the effectiveness of the VOCs. As shown in Figure 2, at $5{ }^{\circ} \mathrm{C}$, exposure to the two lowest concentrations of the VOCs did not completely inhibit growth; only the two highest concentrations tested inhibited P. destructans at this temperature. Figure 3 shows images of the mycelial plugs after three weeks of exposure to these treatments at $15^{\circ} \mathrm{C}$. The mycelial growth of controls and the mycelial growth of plugs exposed to the 0.04 and $0.08 \mu \mathrm{mol} / \mathrm{mL}$ of the $S$ form of 1-octen-3-ol are similar, while the $\mathrm{R}$ enantiomer and racemic form of 1-octen-3-ol showed growth inhibition, as did the mycelial plugs exposed to trans-2-hexenal at $0.05,0.1,0.5$ and $1.0 \mu \mathrm{mol} / \mathrm{mL}$.

\subsection{Subculture of Mycelial Plugs after VOC Treatment}

After the three-week VOC exposure, all mycelial plugs were subcultured to new PDA media and incubated for three weeks in the absence of VOCs to determine if the treatments had killed the mycelia (fungicidal effect) or merely inhibited their growth (fungistatic effect). All treatments of trans-2-hexenal at 10 and $15{ }^{\circ} \mathrm{C}$ were fungicidal. At the lower temperature of $5{ }^{\circ} \mathrm{C}$, cultures exposed to 0.05 and $0.1 \mu \mathrm{mol} / \mathrm{mL}$ of trans-2-hexenal showed some growth indicating a fungistatic effect at these two lower concentrations. With the 1-octen-3-ol treatments, the $S$ form was least effective with recovery of mycelial growth at all four concentrations and three temperatures tested (Figure 4). At $10{ }^{\circ} \mathrm{C}$, $0.08,0.4$ and $0.8 \mu \mathrm{mol} / \mathrm{mL}$ racemic 1 -octen-3-ol was fungicidal while $0.04 \mu \mathrm{mol} / \mathrm{mL}$ was fungistatic. Microscopic examination at the end of the incubation period showed some hyphal extensions although this growth was not measurable macroscopically. At $10^{\circ} \mathrm{C}$, the $R$ form of 1-octen-3-ol was fungicidal at 0.4 and $0.8 \mu \mathrm{mol} / \mathrm{mL}$. At $15{ }^{\circ} \mathrm{C}, 0.8 \mu \mathrm{mol} / \mathrm{mL}$ of racemic 1 -octen-3-ol was fungicidal while the $R$ form was fungistatic. At $5{ }^{\circ} \mathrm{C}$, mycelial plugs exposed to $0.8 \mu \mathrm{mol} / \mathrm{mL}$ of either the racemic or the $R$ form showed some recovery after three weeks incubation. 


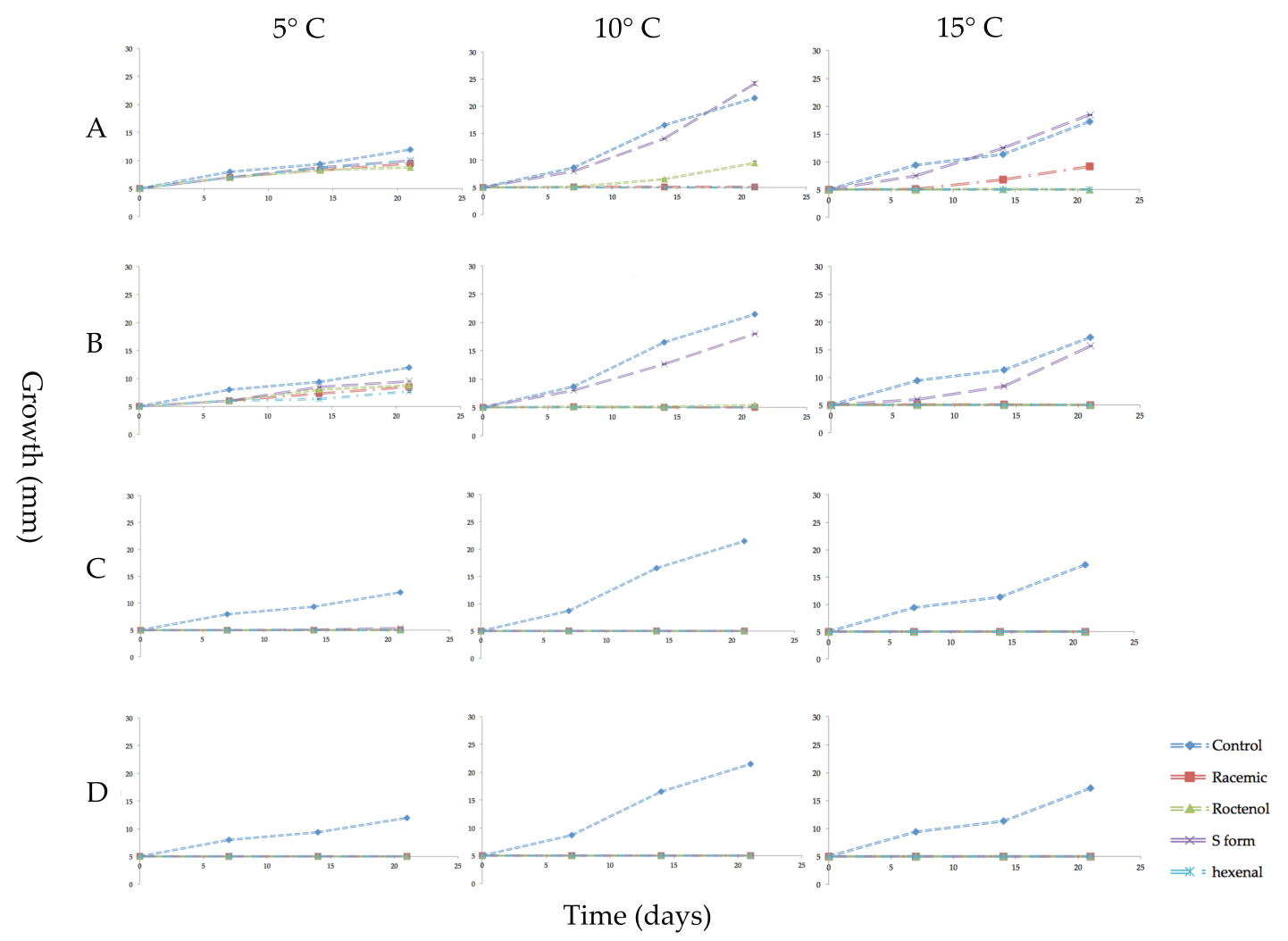

Figure 2. Growth in millimeters $(\mathrm{mm})$ of mycelial plugs of Pseudogymnoascus destructans exposed for 3 weeks to vapors of racemic 1-octen-3-ol, ( $R$ )-(-)-1-octen-3-ol ( $R$ form), (S)-(+)-1-octen-3-ol ( $S$ form), or trans-2-hexenal and cultured at 5,10 or $15{ }^{\circ} \mathrm{C}$. Error bars indicate the standard error of the mean. VOC treatments as follows: (A) $0.04 \mu \mathrm{mol} / \mathrm{mL}$ of the three forms of 1-octen-3-ol or $0.05 \mu \mathrm{mol} / \mathrm{mL}$ of trans-2-hexenal; (B) $0.08 \mu \mathrm{mol} / \mathrm{mL}$ of 1 -octen-3-ol or $0.1 \mu \mathrm{mol} / \mathrm{mL}$ trans-2-hexenal; (C) $0.4 \mu \mathrm{mol} / \mathrm{mL}$ 1-octen-3-ol or $0.5 \mu \mathrm{mol} / \mathrm{mL}$ trans-2-hexenal; (D) $0.8 \mu \mathrm{mol} / \mathrm{mL} 1$-octen-3-ol or $1.0 \mathrm{\mu mol} / \mathrm{mL}$ trans-2-hexenal.

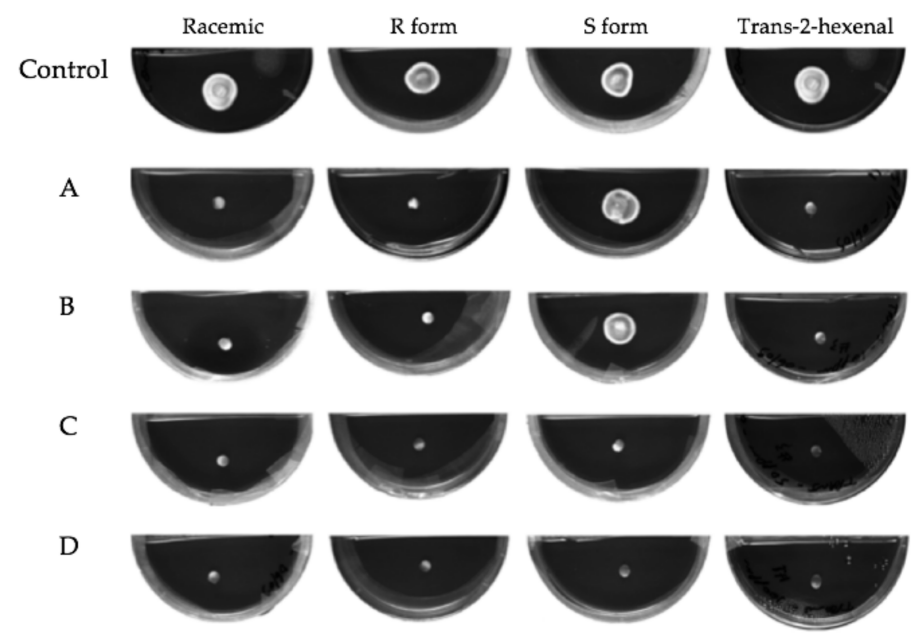

Figure 3. Mycelial plugs of Pseudogymnoascus destructans exposed to vapors of for 3 weeks at $15^{\circ} \mathrm{C}$. VOC treatments as follows: (A) $0.04 \mu \mathrm{mol}$ of the three forms of 1-octen-3-ol or $0.05 \mu \mathrm{mol}$ of trans-2-hexenal; (B) $0.08 \mu \mathrm{mol} / \mathrm{mL}$ of 1 -octen-3-ol or $0.1 \mu \mathrm{mol}$ trans-2-hexenal; (C) $0.4 \mu \mathrm{mol} / \mathrm{mL}$ 1-octen-3-ol or $0.5 \mu \mathrm{mol} / \mathrm{mL}$ trans-2-hexenal; (D) $0.8 \mu \mathrm{mol} / \mathrm{mL}$ 1-octen-3-ol or $1.0 \mu \mathrm{mol} / \mathrm{mL}$ trans-2-hexenal. 


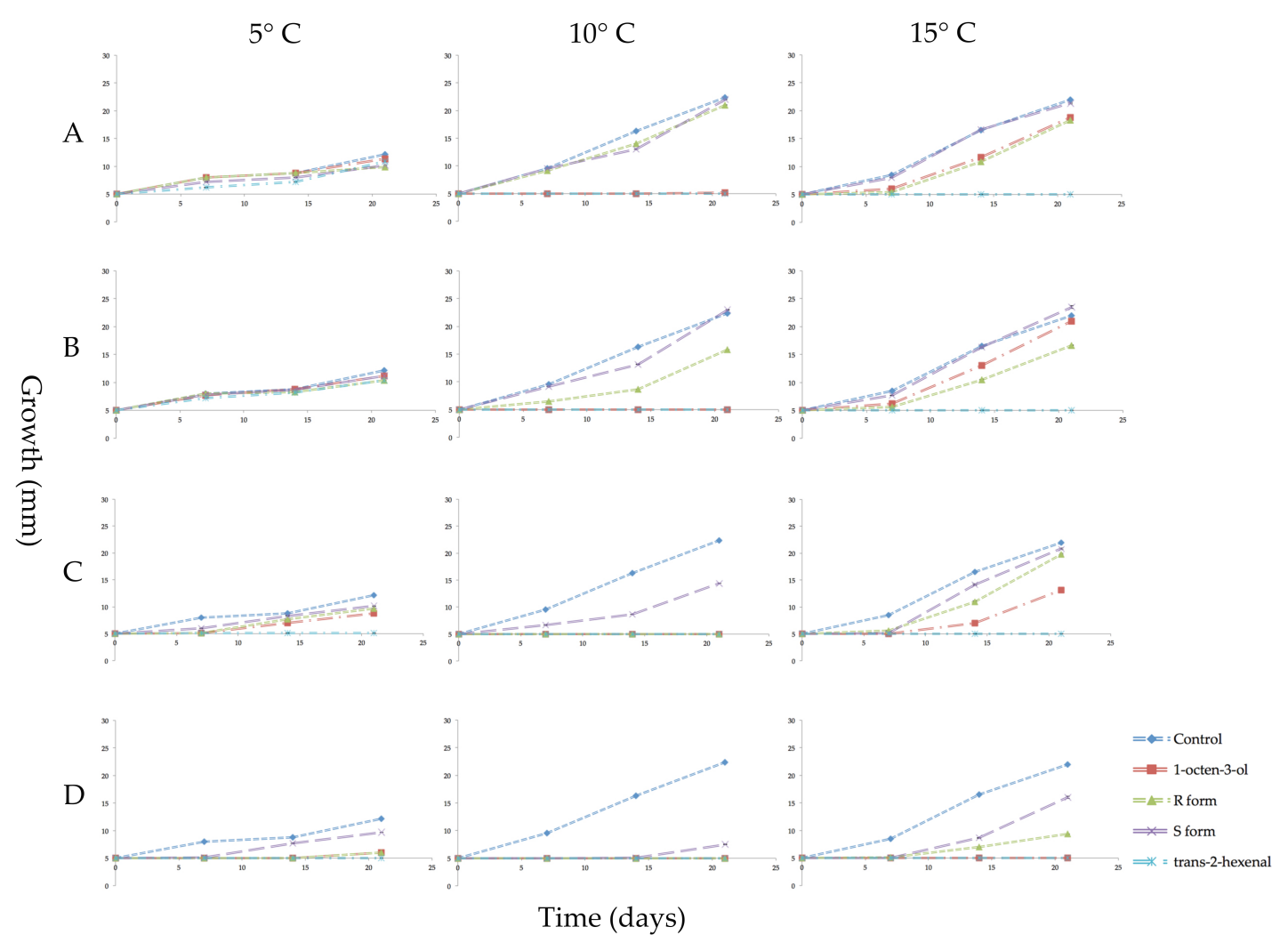

Figure 4. Growth in millimeters ( $\mathrm{mm}$ ) of mycelial plugs of Pseudogymnoascus destructans which were subcultured in ambient air for 3 weeks at 5,10 , or $15{ }^{\circ} \mathrm{C}$ after prior exposure for 3 weeks to vapors of racemic 1-octen-3-ol, $(R)-(-)-1$-octen-3-ol ( $R$ form), (S)-(+)-1-octen-3-ol ( $S$ form), or trans-2-hexenal. Error bars indicate the standard error of the mean. VOC treatments as follows: (A) $0.04 \mu \mathrm{mol} / \mathrm{mL}$ of the three forms of 1-octen-3-ol or $0.05 \mu \mathrm{mol} / \mathrm{mL}$ of trans-2-hexenal; (B) $0.08 \mu \mathrm{mol} / \mathrm{mL}$ of 1-octen-3-ol or $0.1 \mu \mathrm{mol} / \mathrm{mL}$ trans-2-hexenal; (C) $0.4 \mu \mathrm{mol} / \mathrm{mL} 1$-octen-3-ol or $0.5 \mu \mathrm{mol} / \mathrm{mL}$ trans-2-hexenal; (D) $0.8 \mu \mathrm{mol} / \mathrm{mL} 1$-octen-3-ol or $1.0 \mu \mathrm{mol} / \mathrm{mL}$ trans-2-hexenal.

\subsection{Effect of VOCs on Growth from Conidiospores at $10^{\circ} \mathrm{C}$}

The effect of exposure to the volatile phase of these VOCs on growth from conidiospores was studied at $10{ }^{\circ} \mathrm{C}$. After incubation for three weeks at $10^{\circ} \mathrm{C}$, conidiospores exposed to 0.04 $\mu \mathrm{mol} / \mathrm{mL}$ and $0.08 \mu \mathrm{mol} / \mathrm{mL}$ of racemic 1-octen-3-ol, or its $\mathrm{S}$ isomer, gave rise to a few scattered colonies, however no growth was observed for conidiospores exposed to the R enantiomer (Figure 5). At higher concentrations $(0.4$ and $0.8 \mu \mathrm{mol} / \mathrm{mL})$ all three forms of 1-octen-3-ol inhibited conidiospore germination. trans-2-hexenal was more effective than 1-octen-3-ol, since no growth from conidiospores was observed at any of the volatile exposures tested $(0.05,0.1,0.5$ or $1.0 \mu \mathrm{mol} / \mathrm{mL})$. When the plates were removed from the presence of volatiles and incubated for 21 days, conidiospores exposed to $0.08 \mu \mathrm{mol} / \mathrm{mL}$ of the $\mathrm{R}$ enanatiomer of 1-octen-3-ol produced colonies. In contrast, no growth was observed for conidiospores exposed to trans-2-hexenal at any of the concentrations tested. 
A
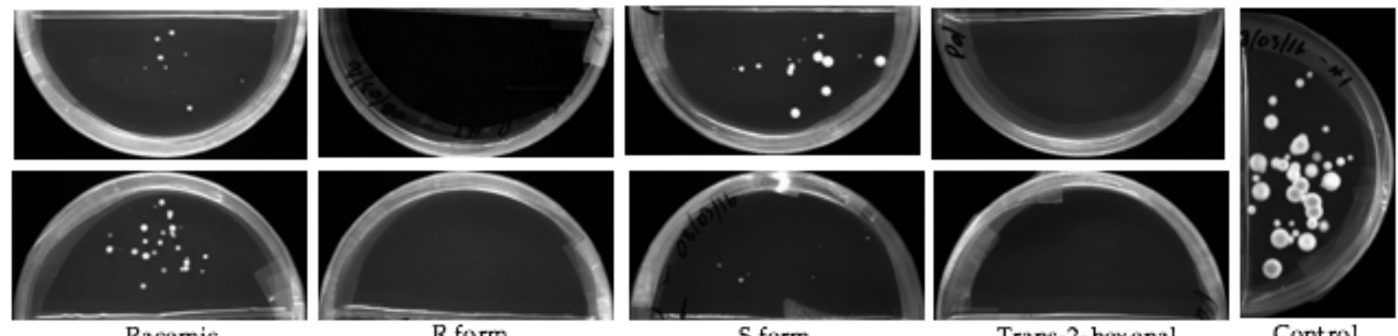

Racemic

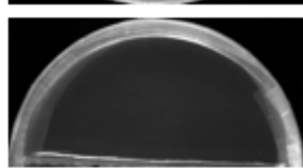

$R$ form

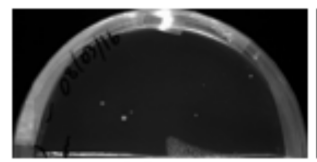

$S$ form
Trans-2-hexenal
Control

Figure 5. The effect of exposure to low concentrations of volatilized racemic 1-octen-3-ol, $(R)-(-)-1-o c t e n-3-o l$ ( $R$ form), (S)-(+)-1-octen-3-ol ( $S$ form) and trans-2-hexenal on growth of $P$. destructans conidiospores after 3 weeks of incubation at $10{ }^{\circ} \mathrm{C}$. VOC treatments as follows:

(A) $0.04 \mu \mathrm{mol} / \mathrm{mL}$ of three enantiomers of 1 -octen-3-ol or $0.05 \mu \mathrm{mol} / \mathrm{mL}$ of trans-2-hexenal;

(B) $0.08 \mu \mathrm{mol} / \mathrm{mL}$ of three enantiomers of 1 -octen-3-ol or $0.1 \mu \mathrm{mol} / \mathrm{mL}$ of trans-2-hexenal.

\subsection{Effect of $0.005,0.01,0.02$ and $0.05 \mu \mathrm{mol} / \mathrm{mL}$ trans-2-hexenal on Conidiospore Growth at $10^{\circ} \mathrm{C}$}

In order to determine if exposure to lower concentrations of trans-2-hexenal were also inhibitory to the germination of $P$. destructans conidiospores, a new exposure system was designed that would allow the testing of lower concentrations of this compound. trans-2-hexenal is not water soluble and we have found that non-polar solvents that can be used to dissolve it also have independent effects on the growth of $P$. destructans. Therefore, in order to accurately test lower concentrations of trans-2-hexenal on conidiospore germination, we increased the volume of our exposure system. In these experiments, a serial dilution of $P$. destructans conidiospores was exposed to trans-2-hexenal vapors in concentrations of $0.005,0.01,0.02$ and $0.05 \mu \mathrm{mol} / \mathrm{mL}$. The three higher concentrations of exposure prevented growth from conidispores, however conidiospores exposed to $0.005 \mu \mathrm{mol} / \mathrm{mL}$ of trans-2-hexenal resumed growth (Figure 6). After a three-week period of incubation, the treated plates were removed from trans-2-hexenal exposure and incubated for another 21 days in the absence of trans-2-hexenal. Conidiospores that had been previously exposed to 0.01 and $0.02 \mu \mathrm{mol} / \mathrm{mL}$ of trans-2-hexenal resumed growth. Conidiospores formerly treated with $0.05 \mu \mathrm{mol} / \mathrm{mL}$ trans-2-hexenal did not resume growth, even after two months, so this concentration was fungicidal to P. destructans.

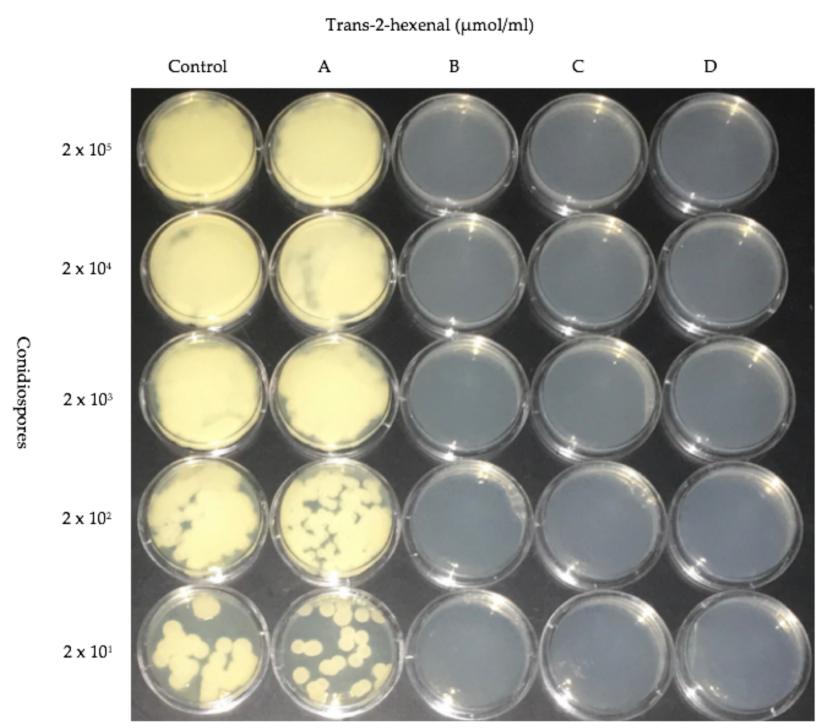

Figure 6. Dilution assay of five different concentrations of $P$. destructans conidiospores treated with trans-2-hexenal. Vapors of VOC as follows: (A) $0.005 \mu \mathrm{mol} / \mathrm{mL}$; (B) $0.01 \mu \mathrm{mol} / \mathrm{mL}$; (C) $0.02 \mu \mathrm{mol} / \mathrm{mL}$; (D) $0.05 \mu \mathrm{mol} / \mathrm{mL}$. 


\section{Discussion}

In addition to the serious negative effects of $P$. destructans on hibernating bats, other fungal pathogens have caused several recent epizootics among vertebrates including Batrachochytrium dendrobatitis, cause of chytridiomycosis in frogs [34], and Ophidiomyces ophiodiicola, cause of snake fungal disease in snakes [35]. There is a pressing need to find environmentally benign antifungal compounds to treat the fungi that cause these devastating wild life diseases.

Volatile organic compounds (VOCs) are small molecules with high vapor pressure that exist in the gaseous state at room temperature [36]. Many of the volatile compounds from natural sources, such as those found in essential oils, have documented antimicrobial activities and are generally recognized as safe (GRAS) by the US Food and Drug Administration [26,33]. For example, at low concentrations, vapors of both hexanal and octanal completely inhibited the radial growth of Aspergillus parasiticus [37]. Similarly, vapors of racemic 1-octen-3-ol and trans-2-hexenal were effective against the mycelial growth of Penicillium chrysogenum [38]. Moreover, exposure to trans-2-hexenal, trans-2-hexen-1-ol, cis-3-hexen-1-ol and 1-hexanol inhibited growth of Fusarium avenaceum and Fusarium graminearum [30]; and trans-2-hexenal inhibited growth of Rhizoctonia solani and Sclerotium rolfsii [39]. We postulated that trans-2-hexenal would be effective against $P$. destructans.

In a previous preliminary study, we tested the eight-carbon alcohol 1-octen-3-ol, and found that when exposed at $15{ }^{\circ} \mathrm{C}$, low concentrations $(0.4$ and $0.8 \mu \mathrm{mol} / \mathrm{mL})$ of racemic 1 -octen-3-ol inhibited growth of $P$. destructans [23]. Mushroom alcohol is a chiral compound and biological systems are known to be sensitive to stereochemistry [24,40]. Therefore, in this current report, we tested to see if the inhibitory effects of the racemic, R-and S- forms of this chiral compound would be different. Indeed, we showed that both racemic 1-octen-3-ol and the $R$ form were more effective than the $S$ form. Moreover, the relative impacts of the three forms of vapors of mushroom alcohol were temperature dependent. When cultures grown at $5{ }^{\circ} \mathrm{C}$ were exposed to low concentrations of 1-octen-3-ol vapors, the effectiveness of all three forms was reduced, likely due to reduced volatility at this low temperature. Because we did not quantitatively monitor the amount of VOC present during the duration of experiments, we recognize that the amount of VOC we report in our exposure figures are the initial concentrations of exposure, that is, maximum amounts. Some loss of VOC likely occurred during the course of the experiments, although we did not detect the distinctive odors of mushroom alcohol or leaf aldehyde.

At low concentrations, the vapors of 1-octen-3-ol were not fungicidal. Rather, mushroom alcohol functioned to retard growth from mycelia and conidiospores. Our data support research on several other fungal species demonstrating the spore germination inhibiting properties of mushroom alcohol, including Agaricus bisporus, Aspergillus nidulans and Penicillium paneum [41-43].

trans-2-hexenal was more effective than 1-octen-3-ol for inhibiting growth from mycelial plugs and conidiospores of $P$. destructans. It completely inhibited growth of mycelial plugs and growth from conidiospores at $0.05 \mu \mathrm{mol} / \mathrm{mL}$. Unlike 1-octen-3-ol, where mycelial growth resumed when the colonies were removed from the presence of the VOC and growth from conidiospores was observed, $P$. destructans exposed to $0.05 \mu \mathrm{mol} / \mathrm{mL}$ of trans-2-hexenal showed growth from neither mycelia nor conidiospores indicating that vapors of trans-2-hexenal were fungicidal at this concentration. Commonly known as leaf aldehyde, trans-2-hexenal is widely distributed in plants [44] where it is a major constituent of the odor of newly mown grass [45]. trans-2-hexenal is also the major VOC in extra virgin olive oil $[46,47]$, where it has been reported to have broad antimicrobial effects [48] and contributes to the ability of olive oil to inhibit the growth of medically important fungi such as Trichophyton mentagrophytes, Candida and Microsporum canis [49]. trans-2-hexenal is an approved food additive by the US Food and Drug Administration [26]. Interestingly, there is also evidence that this compound may have a positive impact on rodent physiology. In controlled laboratory experiments, a mixture of trans-2-hexenal and cis-3-hexanol relieved stress markers in rats [50,51].

Temperature was an important parameter for both the growth of the fungus and the effectiveness of the volatile treatments. In our experiments, control cultures of P. destructans grew best at $10{ }^{\circ} \mathrm{C}$. 
Blehart et al. [10] reported an optimal growth temperature of $P$. destructans between $5^{\circ} \mathrm{C}$ and $10{ }^{\circ} \mathrm{C}$, with only marginal growth above $15^{\circ} \mathrm{C}$. We found that the efficacy of the volatile treatments in inhibiting growth was less pronounced at $5{ }^{\circ} \mathrm{C}$ than at the higher temperatures of $10{ }^{\circ} \mathrm{C}$ and $15{ }^{\circ} \mathrm{C}$. The effectiveness of VOCs has been reported to be dependent on their vapor pressure, with higher temperatures enhancing their effectiveness [32,52,53]. If adopted for use in hibernacula with cold temperatures, it would be important to use appropriate concentrations that take into account the lower efficacy at $5{ }^{\circ} \mathrm{C}$.

Because WNS is associated with hibernation in caves and other enclosed spaces, we envision an intervention whereby bat hibernacula are fumigated with low concentrations of leaf aldehyde (trans-2-hexenal) in such a fashion as to reduce the load of P. destructans. We are currently developing methods for formulating trans-2-hexenal for use in scaled up model habitats and devising methods for testing its toxicity in mammalian tissues.

Acknowledgments: We are grateful to Danielle Fikibar, Lisa LaManna, Brooke Maslo and Richard Veit for their useful insights about bat biology; and to Emma Brush, Scott Cevera, Alanna Cohen, Erick Ferreras and Samantha Haley for their technical assistance. Our project was supported by grants from Bat Conservation International, Inc. Grant RA08112015 and U.S. Fish \& Wildlife Service Grant WNS 2016-6.

Author Contributions: Sally Padhi and Joan W. Bennett designed the experiments and wrote the text of the manuscript; Itamar Dias and Victoria L. Korn performed the experiments, edited the text and formatted the figures and citations.

Conflicts of Interest: The authors declare no conflict of interest.

\section{References}

1. Blehart, D.S.; Hicks, A.C.; Behr, M.; Meteyer, C.U.; Berlowski-Zier, B.M.; Buckles, E.L.; Coleman, J.T.H.; Darling, S.R.; Gargas, A.; Niver, R.; et al. Bat white-nose syndrome: An emerging fungal pathogen? Science 2009, 323, 227. [CrossRef] [PubMed]

2. Turner, G.G.; Reeder, D.M.; Coleman, J.T. A five-year assessment of mortality and geographic spread of white-nose syndrome in North American bats and a look to the future. Bat Res. News 2011, 52, 13-27.

3. Frick, W.F.; Pollock, J.F.; Hicks, A.C.; Langwig, K.E.; Reynolds, D.S.; Turner, G.G.; Butchkoski, C.M.; Kunz, T.H. An emerging disease causes regional population collapse of a common North American bat species. Science 2010, 329, 679-682. [CrossRef] [PubMed]

4. Leopardi, S.; Blake, D.; Puechmaille, S.J. White-Nose Syndrome fungus introduced from Europe to North America. Curr. Biol. 2015, 25, R217-R219. [CrossRef] [PubMed]

5. Field, K.A.; Johnson, J.S.; Lilley, T.M.; Reeder, S.M.; Rogers, E.J.; Behr, M.J.; Reeder, D.M. The White-Nose Syndrome transcriptome: Activation of anti-fungal host responses in wing tissue of hibernating little brown Myotis. PLoS Pathog. 2015, 1, 29. [CrossRef] [PubMed]

6. Langwig, K.E.; Frick, W.F.; Bried, J.T.; Hicks, A.C.; Kunz, T.H.; Kilpatrick, A.M. Sociality, density-dependence and microclimates determine the persistence of populations suffering from a novel fungal disease, white-nose syndrome. Ecol. Lett. 2012, 15, 1050-1057. [CrossRef] [PubMed]

7. Thogmartin, W.E.; Sanders-Reed, C.A.; Szymanski, J.A.; McKann, P.C.; Pruitt, L.; King, R.A.; Runge, M.C.; Russell, R.E. White-nose syndrome is likely to extirpate the endangered Indiana bat over large parts of its range. Biol. Conserv. 2013, 160, 162-172. [CrossRef]

8. Gargas, A.; Trest, M.T.; Christensen, M.; Volk, T.J.; Blehert, D.S. Geomyces destructans sp. nov. associated with bat white-nose syndrome. Mycotoxon 2009, 108, 147-154. [CrossRef]

9. Verant, M.L.; Boyles, J.G.; Waldrep, W., Jr.; Wibbelt, G.; Blehert, D.S. Temperature-dependent growth of Geomyces destructans, the fungus that causes bat white-nose syndrome. PLoS ONE 2012, 7, 1-7. [CrossRef] [PubMed]

10. Blehert, D.S.; Lorch, J.M.; Ballmann, A.E.; Cryan, P.M.; Meteyer, C.U. Bat White-Nose Syndrome in North America. Microbe 2011, 6, 267-273. [CrossRef]

11. Cryan, P.M.; Meteyer, C.U.; Boyles, J.G.; Blehert, D.S. Wing pathology of white-nose syndrome in bats suggests life threatening disruption of physiology. BMC Biol. 2010, 8, 135. [CrossRef] [PubMed] 
12. Warnecke, L.; Turner, J.M.; Bollinger, T.K.; Lorch, J.M.; Misra, V.; Cryan, P.M.; Wibbelt, G.; Blehert, D.S.; Willis, C.K. Inoculation of bats with European Geomyces destructans supports the novel pathogen hypothesis for the origin of white-nose syndrome. Proc. Natl. Acad. Sci. USA 2012, 109, 6999-7003. [CrossRef] [PubMed]

13. Reeder, D.M.; Frank, C.L.; Turner, G.G.; Meteyer, C.U.; Kurta, A.; Britzke, E.R.; Vodzak, M.E.; Darling, S.R.; Stihler, C.W.; Hicks, A.C.; et al. Frequent arousal from hibernation linked to severity of infection and mortality in bats with white-nose syndrome. PLoS ONE 2012, 7, e38920. [CrossRef] [PubMed]

14. Johnson, J.S.; Reeder, D.M.; McMichael, J.W., III; Meierhofer, M.B.; Stern, D.W.; Lumadue, S.S.; Singler, L.E.; Winters, H.D.; Vodzak, M.E.; Kurta, A.; et al. Host, pathogen, and environmental characteristics predict white-nose syndrome mortality in captive little brown Myotis (Myotis lucifugus). PLoS ONE 2014, 9, 1-9. [CrossRef] [PubMed]

15. O’Donoghue, A.J.; Knudsen, G.M.; Beekman, C.; Perry, J.A.; Johnson, A.D.; DeRisi, J.L.; Craik, C.S.; Bennett, R.J. Destructin-1 is a collagen-degrading endopeptidase secreted by Pseudogymnoascus destructans, the causative agent of white-nose syndrome. Proc. Natl. Acad. Sci. USA 2015, 112, 7478-7483. [CrossRef] [PubMed]

16. Cryan, P.M.; Meteyer, C.U.; Blehert, D.S.; Lorch, J.M.; Reeder, D.M.; Turner, G.G.; Webb, J.; Behr, M.; Verant, M.; Russell, R.E.; Castle, K.T. Electrolyte depletion in white-nose syndrome bats. J. Wildl. Dis. 2013, 49, 398-402. [CrossRef] [PubMed]

17. Verant, M.L.; Meteyer, C.U.; Speakman, J.R.; Cryan, P.M.; Lorch, J.M.; Blehert, D.S. White-nose syndrome initiates a cascade of physiologic disturbances in the hibernating bat host. BMC Physiol. 2014, 14, 1-10. [CrossRef] [PubMed]

18. Moore, M.S.; Kunz, T.H. White-Nose Syndrome: A fungal disease of North American hibernating bats. In Encyclopedia of Caves, 2nd ed.; White, W.B., Culver, D.C., Eds.; Elsevier: Waltham, MA, USA, 2012; pp. 904-910. ISBN 978-0-12-383832-2.

19. Moore, M.S.; Reichard, J.D.; Murtha, T.D.; Nabhan, M.L.; Pian, R.E.; Ferreira, J.S.; Kunz, T.H. Hibernating little brown Myotis (Myotis lucifugus) show variable immunological responses to white-nose syndrome. PLoS ONE 2013, 8, 1-9. [CrossRef]

20. Cornelison, C.T.; Gabriel, K.T.; Barlament, C.; Crow, S.A. Inhibition of Pseudogymnoascus destructans growth from conidia and mycelial extension by bacterially produced volatile organic compounds. Mycopathologia 2014, 177, 1-10. [CrossRef] [PubMed]

21. Cornelison, C.T.; Keel, M.K.; Gabriel, K.T.; Barlament, C.K.; Tucker, T.A.; Pierce, G.E.; Crow, S.A. A preliminary report on the contact-independent antagonism of Pseudogymnoascus destructans by Rhodococcus rhodocrous strain DAP 96253. BMC Microbiol. 2014, 14, 1-7. [CrossRef] [PubMed]

22. Raudabaugh, D.B.; Miller, A.N. Effect of trans, trans-farnesol on Pseudogymnoascus destructans and several closely related species. Mycopathologia 2015, 180, 325-332. [CrossRef] [PubMed]

23. Padhi, S.; Dias, I.; Bennett, J.W. Two volatile-phase alcohols inhibit growth of Pseudogymnoascus destructans, causative agent of white-nose syndrome in bats. Mycology 2016, 8, 1-6. [CrossRef]

24. He, L.; Beesley, T.E. Applications of enantiomeric gas chromatography: A review. J. Liq. Chromatogr. Relat. Technol. 2005, 28, 1075-1114. [CrossRef]

25. Mari, M.; Bautista-Baños, S.; Sivakumar, D. Decay control in the postharvest system: Role of microbial and plant volatile organic compounds. Postharvest Biol. Technol. 2016, 22, 70-81. [CrossRef]

26. U.S. Food \& Drug Administration. Subchapter B, Part 172-Food Additives Permitted for Direct Addition to Food for Human Consumption; Subpart F-Flavoring Agents and Related Substances; Sec. 172.515 Synthetic Flavoring Substances and Adjuvants. Available online: https:/ / www.accessdata.fda.gov/scripts/cdrh/ cfdocs / cfcfr/CFRSearch.cfm?fr=172.515\&SearchTerm=polysorbate\%2020 (accessed on 3 April 2017).

27. Thamara, K.J.; Stevenson, P.C.; Hall, D.R.; Belmain, S.R. Effect of volatile constituents from Securidaca longepedunculata on insect pests of stored grain. J. Chem. Ecol. 2005, 31, 303-313.

28. Cao, H.; Baldini, R.L.; Rahme, L.G. Common mechanisms for pathogens of plants and animals. Ann. Rev. Phytopathol. 2001, 39, 259-284. [CrossRef] [PubMed]

29. Sexton, A.C.; Howlett, B.J. Parallels in fungal pathogenesis on plant and animal hosts. Eukaryot. Cell 2006, 5, 1941-1949. [CrossRef] [PubMed]

30. Cruz, A.F.; Hamel, C.; Yang, C.; Matsubara, T.; Gan, Y.; Singh, A.K.; Kuwada, K.; Ishii, T. Phytochemicals to suppress Fusarium head blight in wheat-chickpea rotation. Phytochemistry 2012, 78, 72-80. [CrossRef] [PubMed] 
31. De Lucca, A.J.; Carter-Wientjes, C.H.; Boue, S.; Bhatnagar, D. Volatile trans-2-hexenal, a soybean aldehyde, inhibits Aspergillus flavus growth and aflatoxin production in corn. J. Food Sci. 2011, 76, M381-M386. [CrossRef] [PubMed]

32. Gardini, F.; Lanciotti, R.; Guerzoni, M.E. Effect of trans-2-hexenal on the growth of Aspergillus flavus in relation to its concentration, temperature and water activity. Lett. Appl. Microbiol. 2001, 33, 50-55. [CrossRef] [PubMed]

33. Tripathi, P.; Dubey, N.K. Exploitation of natural products as an alternative strategy to control postharvest fungal rotting of fruit and vegetables. Postharvest Biol. Technol. 2004, 32, 235-245. [CrossRef]

34. Kilpatrick, A.M.; Briggs, C.J.; Daszak, P. The ecology and impact of chytridiomycosis: An emerging disease of amphibians. Trends Ecol. Evol. 2010, 25, 109-118. [CrossRef] [PubMed]

35. Lorch, J.M.; Lankton, J.; Werner, K.; Falendysz, E.A.; McCurley, K.; Blehert, D.S. Experimental infection of snakes with Ophidiomyces ophiodiicola causes pathological changes that typify snake fungal disease. $m B i o$ 2015, 6, 1-15. [CrossRef] [PubMed]

36. Herrmann, A. The Chemistry and Biology of Volatiles, 1st ed.; Wiley: Chichester, UK, 2011; pp. 1-534. ISBN 9780470777787.

37. Wright, M.S.; Greene-McDowelle, D.M.; Zeringue, H.J.; Bhatnagar, D.; Cleveland, T.E. Effects of volatile aldehydes from Aspergillus-resistant varieties of corn on Aspergillus parasiticus growth and aflatoxin biosynthesis. Toxicon 2000, 38, 1215-1223. [CrossRef]

38. Yin, G.; Padhi, S.; Lee, S.; Hung, R.; Zhao, G.; Bennett, J.W. Effects of three volatile oxylipins on colony development in two species of fungi and on Drosophila larval metamorphosis. Curr. Microbiol. 2015, 71, 347-356. [CrossRef] [PubMed]

39. Vaughn, S.F.; Gardner, H.W. Lipoxygenase-derived aldehydes inhibit fungi pathogenic on soybean. J. Chem. Ecol. 1993, 19, 2337-2345. [CrossRef] [PubMed]

40. Maier, N.M.; Franco, P.; Lindner, W. Separation of enantiomers: Needs, challenges, perspectives. J. Chromatogr. A 2001, 906, 3-33. [CrossRef]

41. Chitarra, G.S.; Abee, T.; Rombouts, F.M.; Posthumus, M.A.; Dijksterhuis, J. Germination of Penicillium paneum conidia is regulated by 1-octen-3-ol, a volatile self-inhibitor. Appl. Environ. Microbiol. 2004, 70, 2823-2829. [CrossRef] [PubMed]

42. Noble, R.; Dobrovin-Pennington, A.; Hobbs, P.J.; Pederby, J.; Rodger, A. Volatile C8 compounds and pseudomonads influence primordium formation of Agaricus bisporus. Mycologia 2009, 101, 583-591. [CrossRef] [PubMed]

43. Herrero-Garcia, E.; Garzia, A.; Cordobés, S.; Espeso, E.A.; Ugalde, U. 8-Carbon oxylipins inhibit germination and growth, and stimulate aerial conidiation in Aspergillus nidulans. Fungal Biol. 2011, 115, 393-400. [CrossRef] [PubMed]

44. Hatanaka, A. The biogeneration of green odour by green leaves. Phytochemistry 1993, 34, 1201-1218. [CrossRef]

45. Gardner, H.W. Recent investigations into the lipoxygenase pathway in plants. Biochim. Biophys. Acta 1991, 1084, 221-239. [CrossRef]

46. Kiritsakis, A.K. Flavor components of olive oil-A review. J. Am. Oil Chem. Soc. 1998, 75, 673-681. [CrossRef]

47. Morales, M.T.; Alonso, M.V.; Rios, J.J.; Aparicio, R. Virgin olive oil aroma: Relationship between volatile compounds and sensory attributes by chemometrics. J. Agric. Food Chem. 1995, 43, 2925-2931. [CrossRef]

48. Kubo, A.; Lunde, C.S.; Kub, I. Antimicrobial activity of the olive oil flavor compounds. J. Agric. Food Chem. 1995, 43, 1629-1633. [CrossRef]

49. Battinelli, L.; Daniele, C.; Cristiani, M.; Bisignano, G.; Saija, A.; Mazzanti, G. In vitro antifungal and anti-elastase activity of some aliphatic aldehydes from Olea europaea L. fruit. Phytomedicine 2006, 13, 558-563. [CrossRef] [PubMed]

50. Akutsu, H.; Kikusui, T.; Takeuchi, Y.; Sano, K.; Hatanaka, A.; Mori, Y. Alleviating effects of plant-derived fragrances on stress-induced hyperthermia in rats. Physiol. Behav. 2002, 75, 355-360. [CrossRef]

51. Ito, A.; Miyoshi, M.; Ueki, S.; Fukada, M.; Komaki, R.; Watanabe, T. "Green odor" inhalation by rats down-regulates stress-induced increases in Fos expression in stress-related forebrain regions. Neurosci. Res. 2009, 65, 166-174. [CrossRef] [PubMed] 
52. Joo, M.J.; Merkel, C.; Auras, R.; Almenar, E. Development and characterization of antimicrobial poly(1-lactic acid) containing trans-2-hexenal trapped in cyclodextrins. Int. J. Food Microbiol. 2012, 153, 297-305. [CrossRef] [PubMed]

53. Lanciotti, R.; Gianotti, A.; Petrignani, F.; Belletti, N.; Guerzoi, M.E.; Gardini, F. Use of natural aroma compounds to improve shelf-life and safety of minimally processed fruits. Trends Food Sci. Technol. 2003, 15, 201-208. [CrossRef] article distributed under the terms and conditions of the Creative Commons Attribution (CC BY) license (http://creativecommons.org/licenses/by/4.0/). 